\title{
STORAGE MEASURES AS COMPENSATORY TECHNIQUES FOR URBAN LOWLANDS FLOOD CONTROL
}

\author{
M. G. MIGUEZ, A. P. VERÓL, F. C. B. MASCARENHAS \& R. B. SANTOS \\ Universidade Federal do Rio de Janeiro, Brazil.
}

\begin{abstract}
Urban flood problems are being aggravated in growing cities. The process of urbanisation generally tends to supress natural retention areas, removing natural vegetation and producing large impervious areas. Besides, the traditional urban drainage approach, comprising mainly canalisation measures, showed to be potentially unsustainable, tending to transfer floods to downstream. Gradually, in the past recent years, this practice has been complemented or replaced by new concepts considering the use of distributed interventions to approximately recover flow patterns prior to the urbanisation. In Brazilian great cities, drainage systems' design started to incorporate the use of the so-called Compensatory Techniques, which aim to compensate the effects for the urbanisation process over the water cycle. In this context, detention and retention reservoirs have been conceived as potential adequate solutions. Departing from a Municipality proposition for a new urban development in Guerenguê River catchment, west zone of Rio de Janeiro, and considering the concept of compensatory techniques applied to the urban drainage, an alternative configuration for the drainage system is proposed in the catchment scale, and compared with the critical present situation. In this alternative proposal, besides the Municipality actions, a complementary set of storage measures distributed along the riverine areas was considered. Additionally, local measures, composing multifunctional landscapes on the microdrainage scale, were also introduced to face local inundation problems. The scenarios assessment was supported by mathematical modelling. Modelling results showed that, at present situation, great part of the catchment suffers from flooding, with water depths that usually range from $0.15 \mathrm{~m}$ to $1.50 \mathrm{~m}$. In critical areas, flooding may surpass the $1.50 \mathrm{~m}$ high level. The introduction of the compensatory techniques was capable of significantly changing this situation. However, for a more effective result, land use planning must also be addressed in the context of flood control.
\end{abstract}

Keywords: Compensatory techniques on urban drainage, flood control, mathematical modelling, MODCEL, storage measures.

\section{INTRODUCTION}

Growing cities are increasingly suffering from urban floods as a consequence of the urbanisation process itself. The fast urban development experienced after the Industrial Revolution was responsible for several significant changes in the urban water cycle, mainly due to the vegetation removal, the suppression of natural retention areas, and the high impervious rates. In the origin of this process, the traditional approach commonly adopted to face these problems comprised canalisation measures, mainly due to sanitation needs. This approach, however, showed to be unsustainable in terms of urban stormwater management, tending to transfer flood problems rather than solving them. In recent decades, the problem of urban flooding has been discussed from a new perspective. The recognition of this situation made the urban flood control concepts evolve along time towards sustainability. The traditional canalisation approach for flood control has been complemented or replaced by new concepts that consider a systemic approach, with distributed interventions over the catchment surface, even outside the drainage system, intending to recreate, as near as possible, the flow patterns prior to the urbanisation, recovering natural hydrologic functions. This way, it is considered more important to treat the problem from its source, avoiding simple end-of-pipe solutions. 
Recent practices of drainage system projects in Brazilian great cities have introduced the use of the so-called Compensatory Techniques on Urban Drainage [1], which aim to compensate the effects for the urbanisation process over the water cycle. However, the spatial and temporal variability of the phenomenon gives particular characteristics to each catchment. In this context, a systemic evaluation of flood control projects is needed, providing adequate spatial coverage without superimposing effects in time.

A fundamental tool aid to proceed with an integrated analysis of how the drainage system works, coupled with flow surface processes and integrated with urban landscape features, is the mathematical modelling. When mathematical models are soundly constructed in close relation with the physic situation that they intend to reproduce, and considering that they are adequately adjusted by the calibration process, they may be able to forecast future scenarios, in differently combined situations, supporting the planning process and being capable to define the configuration of design arrangements.

This work, in particular, proposes the implementation of a set of reservoirs in the west zone of Rio de Janeiro City, departing from a proposition of the Municipality [2], in the context of the use of compensatory techniques on urban drainage, in order to allow their use as multifunctional landscapes, integrated with urban surroundings and working for laminating major flood events. Most detention basins in Brazil comprise only the storage effects. Although it may be considered an increasing tendency, there are still few multifunctional landscapes working as reservoirs for flood control purposes. However, the possibility of combining recreational aspects, sports, landscaping, and flood control may be a key element to optimise public resources applications, especially in developing countries, where the investment capacity tends to be limited. The flood problem is, then, discussed in a systemic perspective and land use control is also addressed as a key element in this context. The case study presented to support the argumentation developed in this paper refers to the Guerenguê River Basin, in a developing urban area of the city. All the scenarios discussed in the paper are supported by a mathematical modelling tool.

\section{STORAGE MEASURES AS COMPENSATORY TECHNIQUES ON URBAN DRAINAGE FOR FLOOD CONTROL}

Traditional practices in urban drainage tend to act on the consequences of floods, which are the increased superficial water volumes and faster flow velocities. These practices frequently transfer problems instead of solving them. The traditional canalisation approach for flood control has been complemented or replaced by new concepts that consider a systemic approach, with distributed interventions over the catchment intending to reproduce as well as make the flow patterns possible prior to the urbanisation. Compensatory techniques on urban drainage, a concept consolidated by Batista et al. [1] in Brazil, is an optional approach that goes towards this aim.

In the last decades, several different conceptions have been proposed with some minor differences among them. All of them, however, tend to consider the urban drainage questions in an integrated way, trying to recover natural characteristics of the hydrological cycle, while adding value to the city itself. In this context, some of these new concepts can be mentioned: Best Management Practices BMPs [3, 4], Low Impact Development - LID [5-7], Sustainable Urban Drainage System - SUDS [5, 8] and Water Sensitive Urban Design - WSUD [9-11].

In Brazil, the concept developed and formalised by Baptista et al. [1] (the compensatory techniques) means the introduction of several different measures, focusing on infiltration and storage capacity, with the aim of compensating urban impacts on the hydrological cycle. 
Hall and Porterfield [12] stressed the necessity of finding solutions to recover the harmonic design of communities, arranging their growth in a sustainable way, while preserving the landscape characteristics, considering also the importance of run-off control. Techniques such as detention or retention reservoirs for flood control can also integrate harmoniously into the urban environment as they can be designed as recreational areas in dry weather and assume the characteristics of multifunctional landscapes $[13,14]$.

The integration of drainage solutions with the revitalisation and enhancement of urban space can be an important way to solve the problem of flooding, once the possibility of designing actions distributed over the entire urbanised catchment, avoiding the traditional end-of-pipe solutions, allows the optimisation of public investments in multiple purpose works and a possible better acceptance by the communities affected by the built environment improvement.

\section{CASE STUDY: THE GUERENGUÊ RIVER CATCHMENT}

The case study is located in the west zone of Rio de Janeiro, Brazil, specifically on Guerenguê River catchment. The majority of the river catchment area is occupied by the Jacarepaguá neighbourhood. Extensive lowlands compose the region, with hill slopes on its upper reaches. More than 500,000 inhabitants live in Jacarepaguá region, where, in social terms, human development is considered to be from medium to high. The main tributaries of Guerenguê River are Monjolo River, Areal River and Engenho Novo River, as is shown in Fig. 1.

The upstream reach of Engenho Novo River is located at a park, in a preserved forest area of $411 \mathrm{~m}$ of elevation. Areal River is the first one to encounter Engenho Novo River at its left margin.

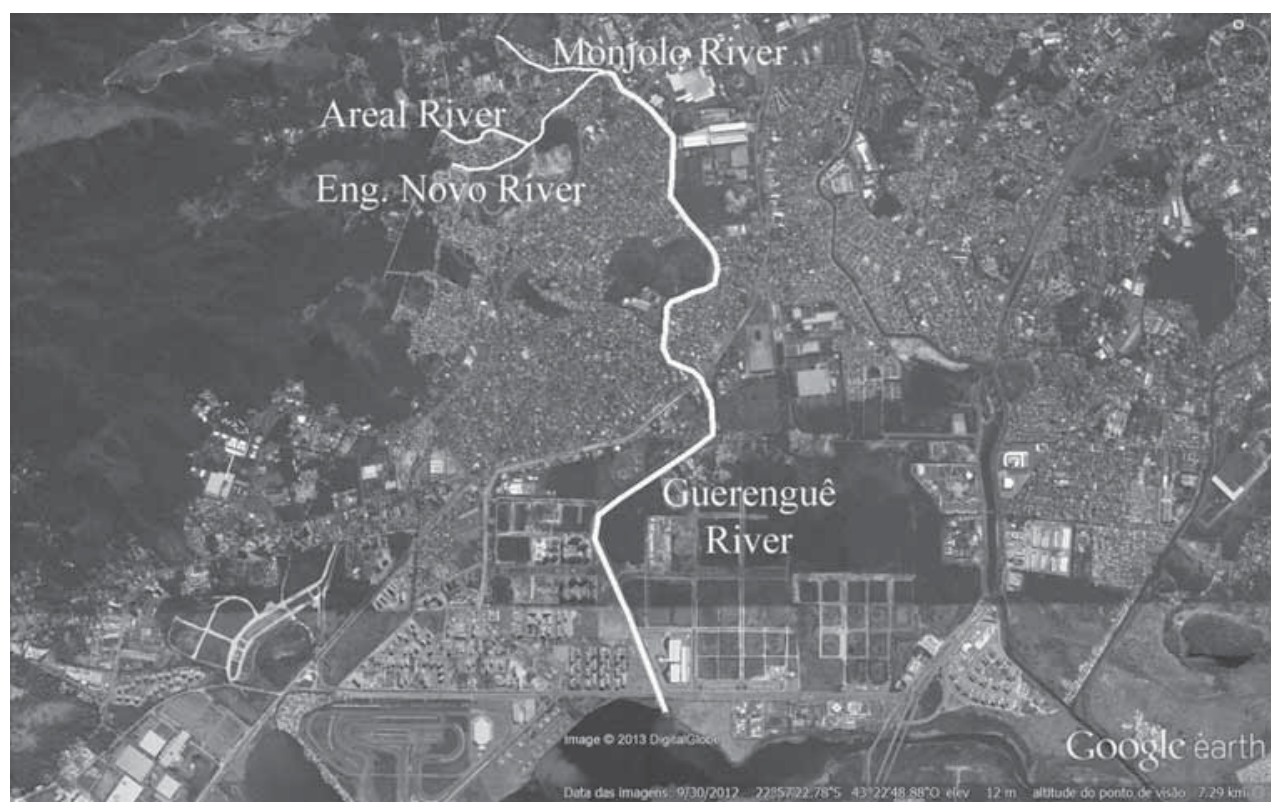

Figure 1: Guerenguê River and its main tributaries [15]. 
Then, Monjolo River also enters Engenho Novo River, finally forming Guerenguê River. The outfall of Guerenguê River occurs in a complex of coastal lagoons.

Urban occupation is increasing and there are several problems related with urban floods and sanitation aspects. Wastewaters pollute the rivers and the downstream lagoon complex suffers from eutrophication processes. Besides that, there are numerous irregular occupations near riverine areas, which aggravate flood problems.

Considering the choice of Rio de Janeiro to host the XXXI Olympic Games, in 2016, and the fact that sport functions as a sponsor of social inclusion and of regional development, it is expected that there will be a further development of the city due to the magnitude of this event. Large investments are planned and are already being executed in order to provide the city with the required infrastructure for the 2016 Olympic Games. The construction and adequacy of sports infrastructure is scheduled for several areas of the city, but a significant amount of them will be located in the western area of Rio de Janeiro city, where the studied catchment lays.

This event will lead to changes of land use and occupation in this region. Though, Guerenguê River catchment will experience a process of intense modification in land use, especially in the downstream areas, which will put at risk important green areas, covered with natural vegetation. The potentiality for the application of storage measures as compensatory techniques on urban drainage for flood control is identified here, to ensure a balanced growth, avoiding worsening of the local environmental conditions and developing the catchment in a sustainable manner.

\subsection{Urban design actions}

Taking the history of catastrophic floods in the region into account, the Municipality of Rio de Janeiro proposed a restructuring project in a Community called Juliano Moreira, providing the creation of retention reservoirs associated with the canalisation and restoration of river reaches. The project also includes the removal of illegal buildings in marginal areas of the rivers and relocating families within the community.

Originally located in the neighbourhood of Jacarepaguá, occupying $77 \mathrm{~km}^{2}$ of a large green area of the upstream reaches of the catchment, Juliano Moreira officially became a neighbourhood of Jacarepaguá Administrative District in September 2009. This region was, then, included in the Brazilian Growth Acceleration Program [16], allowing the community to receive improvements in its infrastructure, such as paving, construction of water networks and sewage systems. The restructuring of the Community, includes interventions in the infrastructure, urbanisation, housing and land tenure, reaching a population of about 20,000 people. The whole project is estimated at approximately 55 million euros.

Based on the proposition made by the Municipality [2], concerning the implementation of reservoirs that altogether had an approximate area of $33 \mathrm{ha}$, the authors modelled this area with MODCEL and verified that the obtained result showed the right choice for the new urban development expected for this region. This contribution, however, did not solve the problem of lower catchment areas, making it necessary to include other compensatory measures distributed over the catchment to reduce general flooding. With the aid of field visits and satellite images, it was possible to identify other areas of interest capable to receive flood control measures. A set of measures, including new reservoirs distributed over the catchment, removal of marginal occupation and decrease in the ground level of some riverine areas associated with floodplains, was proposed and introduced in MODCEL simulations, complementing the effects of the Municipality project. Figure 2 presents all the proposed reservoirs, the original and the additional ones. 


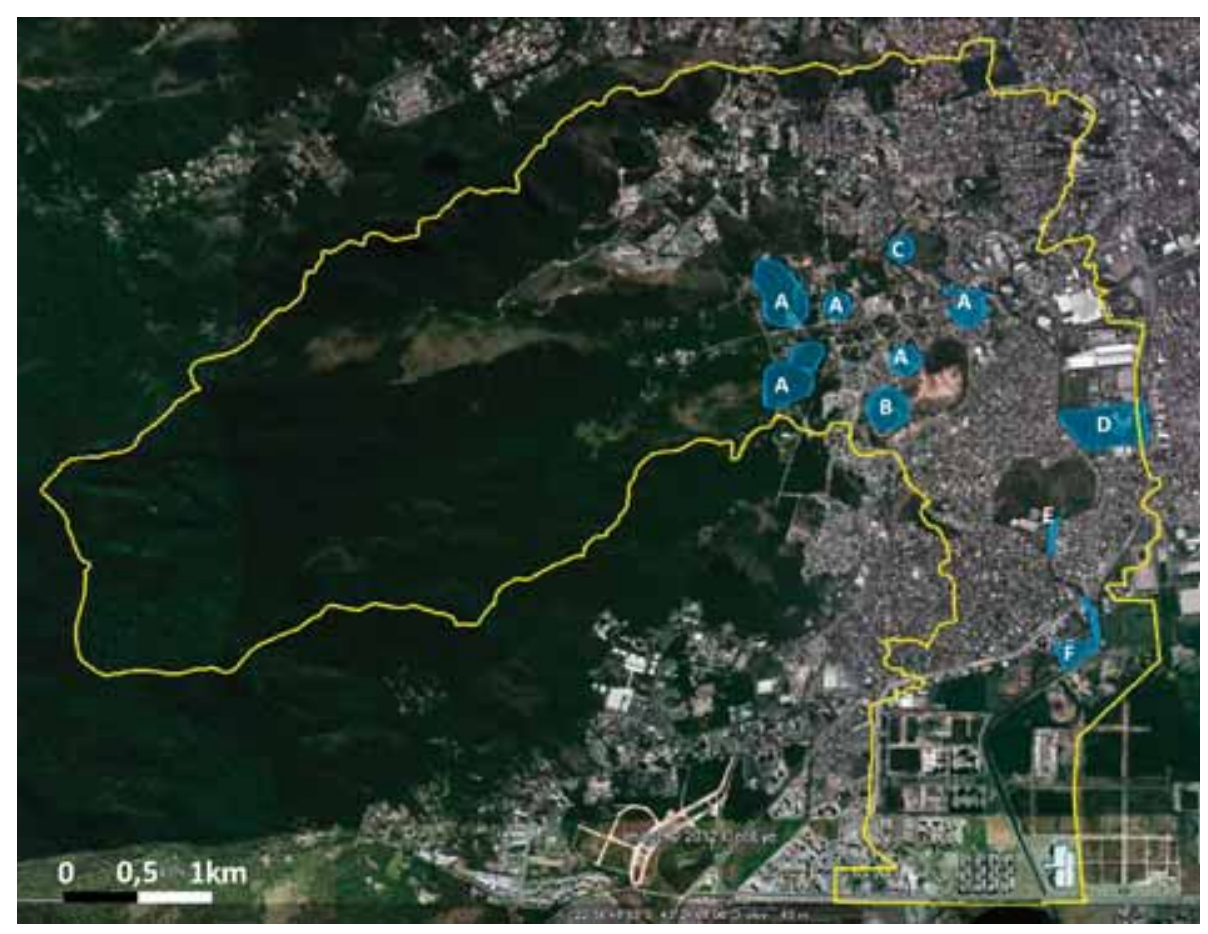

Figure 2: Reservoirs proposal for Juliano Moreira Community [15].

It is important to recognise that this is an important public initiative, but yet developed in a local basis. The downstream reaches of the catchment are suffering with a great housing market pressure and there is still a lack of control on imperviousness rates and the use of landfills on lowlands areas. There are also several other irregular habitations on risk areas along riverbanks.

In the sequence, a brief description is presented of the interventions proposed and identified by letters (A, B, C, D, E and F) at Fig. 2:

- Intervention "A" - set of retention reservoirs proposed by the Municipality, integrated with the design of the planned urban development. These reservoirs will have permanent pools, with their bottom elevations assumed equal to that of the nearest river reaches modelled. When the reservoirs did not communicate to any river stream, their depths were considered equal to $1.0 \mathrm{~m}$.

- Intervention "B" - retention reservoir proposed jointly with the implementation of a new recreational public area, in a multifunctional landscape arrangement occupying a riverine area.

- Intervention " $C$ " - detention reservoir proposed in a green private area (that has to be acquired by the Municipality or the private owner has to be somehow compensated for this use), which will communicate with Monjolo River by a weir.

- Intervention " $D$ " - detention reservoir proposed in an industrial area free of occupation on the left Guerenguê River margin. This area is supposed to be acquired and transformed in a public park that could serve the residential area of the opposed margin (at the right bank). Due to its size, this detention reservoir may be designed with different terrace levels. The lower elevations would be flooded more frequently, preserving the park to be completely flooded for the majority of the rainfall events, which occur more rarely. 
- Intervention "E" - removal of irregular urban occupation on the right bank of Guerenguê River, followed by the implementation of a major secondary channel section, by lowering this area.

- Intervention " $F$ " - removal of irregular urban occupation on the right bank of Guerenguê River, lowering the riverine areas to allow a reconnection of the river with part of its flood plain.

An alternative urban revitalisation approach for this area, not explored in this paper, could eventually propose a greenway, working as a linear park, along the right margin of Guerenguê River, integrating and extending some of the proposed interventions (for instance, connecting interventions $\mathrm{E}, \mathrm{F}$ and the most downstream of the A interventions).

\subsection{Simulation scenarios}

The study developed here intends to simulate the present situation of the catchment, to establish the reference for comparisons. In the sequence, storage actions, based on the compensatory techniques approach, are proposed, considering the availability of open spaces in the catchment. The criticality of flooding problems in the catchment arises in these scenarios and this will be the stage for the discussion developed in this paper.

\subsection{Mathematical modelling}

In the context of the present work, it is essential to reproduce the situation of surface flows integrated with the urban drainage system and the urban solutions proposed by the Municipality for the region.

For this purpose, MODCEL was used [17-19], a hydrodynamic computer model that allows an adequate representation not only of the channel flows, but also of the runoff over flood plains in urbanised areas. This model is able to represent the various interactions and the future interventions in the region, even when dealing with urban design outside the drainage system.

The results obtained for the simulated scenarios allow a comparative evaluation, verifying the effect obtained with the proposed measures. 157 cells were used by the mathematical model, comprising channel cells, natural and urbanised superficial cells and reservoir cells. The main link used in the flow net was the Saint-Venant dynamic equation.

The recurrence time adopted for calculating the design rainfall was 20 years, as recommended by Rio de Janeiro Municipality for macro-drainage projects at the time of the development of this project, and the duration of the rain coincides with the concentration time for the Guerengue River catchment, which was 225 minutes. Downstream coastal lagoon system was considered with its higher level, as a boundary condition.

The calibration process for this simulation was considered as an alternative approach. There was no simultaneous information available on rainfall and water levels in the main rivers. However, a flood map, with water levels in the flood plains, was available. This map was constructed based on two previous major events. Considering this information and assuming that the design rainfall of 20 years of recurrence time is of similar magnitude of the observed events, the model was adjusted to approximately represent the available flood map. Table 1 shows the results of the calibration process for the considered control points and Fig. 3 shows the representation of the modelled present situation.

As expected, the modelled results show an unfavourable situation in the region, with water levels above $1.5 \mathrm{~m}$ in the middle reaches of the Guerengue River and several other points with significant flooding distributed throughout the catchment.

Considering the Municipality proposal and the additional interventions proposed by the authors, a new scenario was simulated, based on the information given previously, as illustrated in Fig. 2. The 
Table 1: Calibration results.

\begin{tabular}{lcc}
\hline Site & $\begin{array}{c}\text { Target water } \\
\text { depths (m) }\end{array}$ & $\begin{array}{c}\text { Calibrated water } \\
\text { depths (m) }\end{array}$ \\
\hline Castor Street - Bandeirantes Road & $0.30-0.50$ & 0.21 \\
Castor Street - Floreal Street & $0.75-1.00$ & 0.90 \\
Vila Aurora Street - André Rocha Street & $1.00-1.50$ & 1.59 \\
Guerenguê Road - Beira Lima Avenue & $0.15-0.20$ & 0.30 \\
Onil Machado Gitahy Street - Clodomir Lucas dos Reis Street & $0.75-1,00$ & 0.90 \\
Coronel Willyan Street - Clóvis da Silva Street & $0.30-0.50$ & 0.36 \\
Coronel Willyan Street - Bandeirantes Road & $0.30-0.50$ & 0.43 \\
Aires Ferreira Street & $0.75-1.00$ & 0.66 \\
Outeiro Santos Road - Luciano de Rose Street & $0.75-1.00$ & 0.65 \\
\hline
\end{tabular}

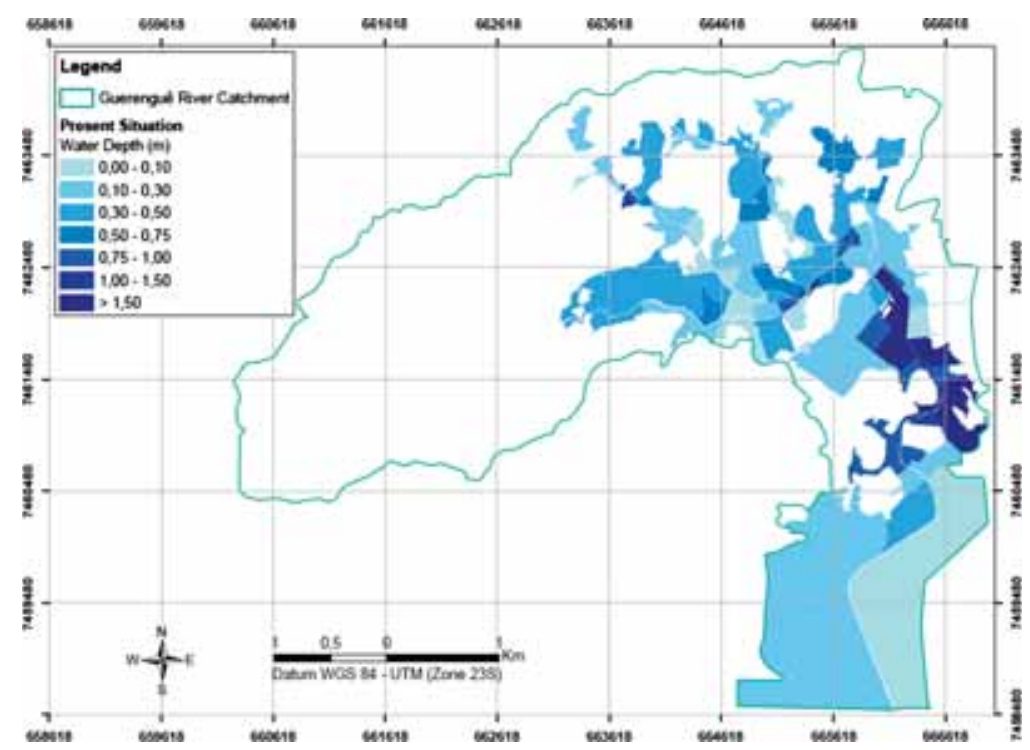

Figure 3: Present situation flood map.

results of this new scenario, considering the proposition of reservoirs as storage measures, are shown in the flood map presented in Fig. 4.

A general flood reduction was observed, with the introduction of the reservoirs. This result emphasises the importance of the spatial distribution of the interventions over the catchment. However, some regions still present high water depths, which show the need for additional compensatory techniques to solve the problem. It is important to stress that micro-drainage problems were not treated in these simulations; and some flooding problems are clearly related with this motion, once it is noticed that there are flooded areas not directly related to the macro-drainage system.

Downstream areas, near the outfall at the coastal lagoon system, turned out to be less sensible to changes in flow patterns. These are very low areas that could be considered proper for a humid park or wetland. Its occupation is risky and may interfere negatively in the upstream flooding levels, by 


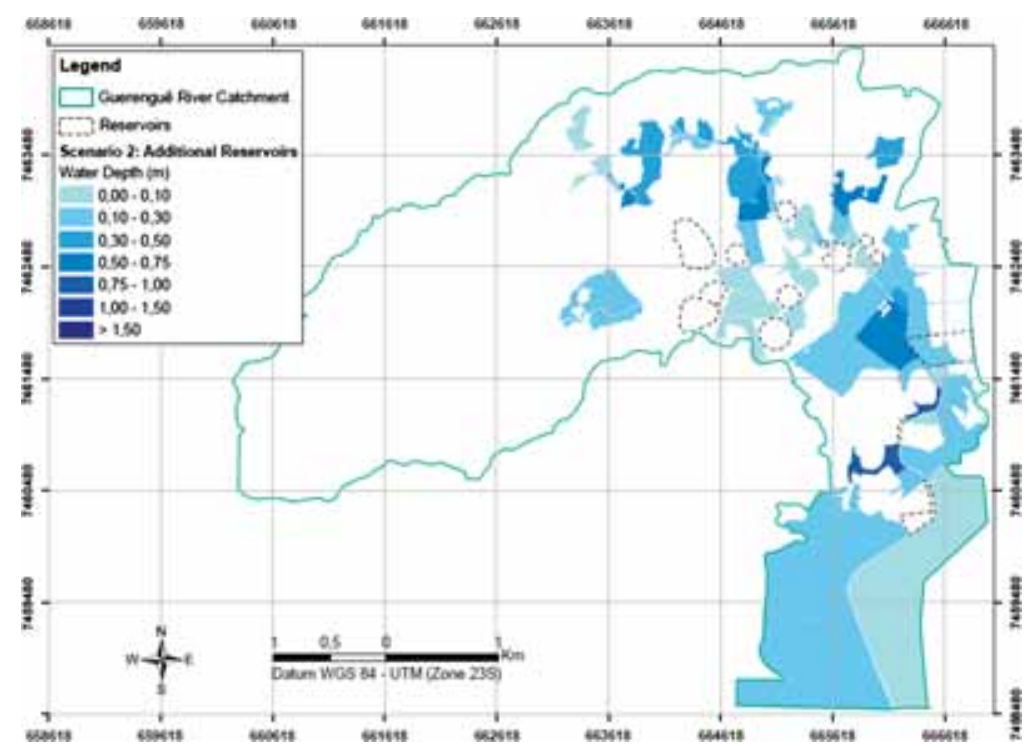

Figure 4: Reservoirs as storage measures flood map.

reducing the space required for the natural floods. However, this area is being landfilled for new construction enterprises, without explicitly considering these questions. Already planned for this area is the construction of a great business centre, called Metropolitan Centre (Fig. 5), which probably will have a great importance, similar to that of the actual business centre, located in the central part of the city. Alternatively, it would be possible to preserve some humid areas and free space for controlled flooding in green areas, if part of the predicted blocks were converted into parks. It is important to combine urban development, land use and flood control.

On the other hand, another important question is: why even with a set of several reservoirs distributed over the basin, flooding still occurs in the modified situation and housing pressures are high? This result strongly points to the need of urban land use control on future developments, in order to minimise flow generation and this is the most important expansion area of the Rio de Janeiro City. In order to treat this problem, some typical urban public spaces, like squares or parks, could be used to store stormwaters from microdrainage systems, before releasing them into the macrodrainage. This way, integrated actions over the urbanised catchment, aiming the urban space revitalisation and the natural environment conservation, may be achieved by the incorporation of hydraulic functions to urban elements [13, 14]. These multifunctional landscapes help us to combine Hydraulic Engineering, Architecture and Urbanism knowledge to provide an improved built environment. An example of this possibility is being presented in the next item.

\subsection{Integrating urban design and flood control}

The integration of urban design and flood control is a possibility to be considered in urban revitalisation projects or urban developing circumstances. The use of multifunctional landscapes appears as an opportunity to spread on source flow generation controls over the basin. In the case of Guerenguê catchment, this alternative is materialised in an example related to a detention reservoir, proposed by the authors in a public space called Clarim Square, aiming to laminate major flood events. This square is very near to a second public space, called Sentinela Square, and both were considered in 


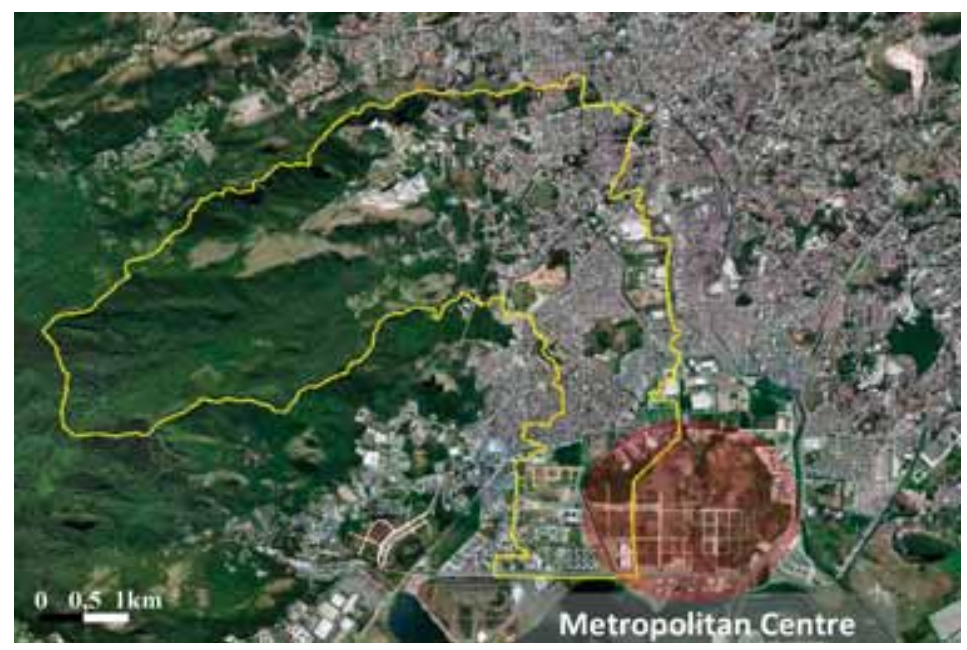

Figure 5: Future localisation of the Metropolitan Centre, near the downstream area of the Guerenguê catchment [15].

the final design solution. This intervention area is located at the upstream reach of Guerenguê River catchment, in the upper-medium portion of Monjolo River sub-catchment.

The proposed storage measure considers the design of an open detention reservoir, settled off-line at Clarim Square, with its main inlet placed upstream, at Sentinela Square. This inlet is designed to let the one year recurrence food by-pass the square, avoiding frequent interferences with its other uses. This design decision implies that only major events will occupy the square, due to the concern of its multifunctional purposes. The outfall of the reservoir is composed by a single orifice and discharges by gravity, without the need of any specific operation. The design criteria considered, for the definition of the detention volume and the outfall discharges, used the premise of recovering the preurbanisation peak flow for the drainage area. A sports court, with concrete floor, will occupy the lowest level. This layout intends to simplify maintenance and cleaning. Landscaping should integrate all these elements. Figure 6 shows the schematic conception for the project.

The entire upstream catchment, collected in the drainage system, may contribute to the square reservoir. Besides, the streets of the near square surroundings have their superficial flows also collected and directly sent to the reservoir, through a special set of inlets, settled transversely to these streets. The total contribution area has approximately $319,000 \mathrm{~m}^{2}$. The time of concentration estimated for the local catchment was 12 minutes. The main drainage path has approximately $800 \mathrm{~m}$ and its medium slope is $0.018 \mathrm{~m} / \mathrm{m}$. The time of recurrence considered for the design rainfall was the same of the entire basin simulation, that is, 20 years.

The results obtained with the Clarim Square reservoir dropped the flooding levels up to $90 \%$ for its surroundings. For the whole basin simulation, however, although local inundation was under control, it was observed that discharges to downstream did not lower significantly. This result shows that the flooded areas of the surroundings of the square site already acted as an undesired reservoir, inundating buildings and public spaces, previously to the proposed detention measure. The detention reservoir at Clarim Square helped us to reorganise flooding patterns, transferring the inundation from the streets to the storage area of the square. This is an important effect that complements the previous storage actions proposed for main river courses of the basin. This kind of intervention could be used associated with other minor public spaces to cover the basin surface as a whole.

Table 2 summarises the information related with the detention reservoir design and results. 


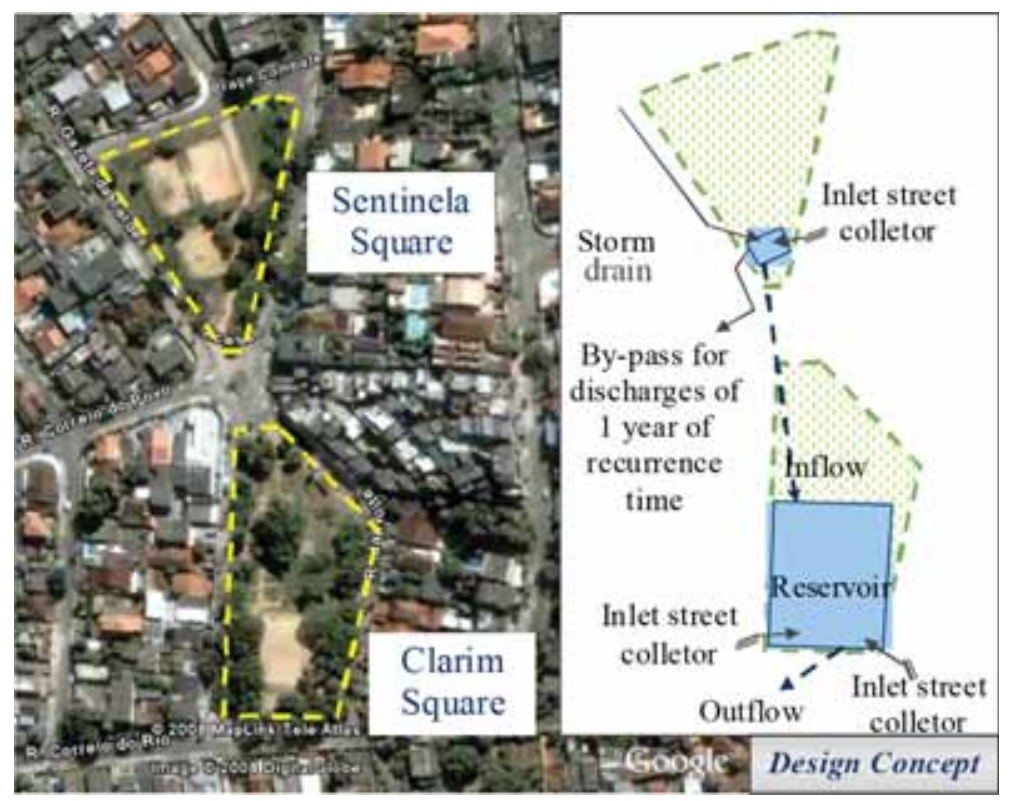

Figure 6: Location and schematic conception of the proposed detention reservoir in Clarim Square.

Table 2: Design details for the multifunctional square detention reservoir.

\begin{tabular}{|c|c|}
\hline Variable & Value \\
\hline $\begin{array}{l}\text { Design discharge for the drainage system, for } 20 \text { years of } \\
\text { time of recurrence }\end{array}$ & $6.02 \mathrm{~m}^{3} / \mathrm{s}$ \\
\hline $\begin{array}{l}\text { Design discharge for the surrounding streets, for } 20 \text { years } \\
\text { of time of recurrence }\end{array}$ & $1.91 \mathrm{~m}^{3} / \mathrm{s}$ \\
\hline $\begin{array}{l}\text { Design discharge for the drainage system, for } 1 \text { year of } \\
\text { time of recurrence }\end{array}$ & $3.35 \mathrm{~m}^{3} / \mathrm{s}$ \\
\hline Inflow discharge to the reservoir at Clarim Square & $6.02+1.91-3.35=4.58 \mathrm{~m}^{3} / \mathrm{s}$ \\
\hline $\begin{array}{l}\text { Pre-urbanisation discharge, for } 20 \text { years of time of } \\
\text { recurrence, for the whole area contributing to the square }\end{array}$ & $5.00 \mathrm{~m}^{3} / \mathrm{s}$ \\
\hline $\begin{array}{l}\text { Maximum discharge allowed at the outlet of the square } \\
\text { reservoir, in order to maintain pre-urbanisation discharge } \\
\text { peak to downstream: }\end{array}$ & $5.00-3.35=1.65 \mathrm{~m}^{3} / \mathrm{s}$ \\
\hline Total volume of the storage area & $2120 \mathrm{~m}^{3}$ \\
\hline $\begin{array}{l}\text { Orifice at the outfall of the multifunctional reservoir at } \\
\text { Clarim Square }\end{array}$ & Diameter of $0.30 \mathrm{~m}$ \\
\hline Maximum depth in the reservoir & $0.89 \mathrm{~m}$ \\
\hline Maximum reservoir outfall discharge & $0.12 \mathrm{~m}^{3} / \mathrm{s}\left(<1.65 \mathrm{~m}^{3} / \mathrm{s}\right)$ \\
\hline $\begin{array}{l}\text { Total discharge to downstream (deviation plus reservoir } \\
\text { outfall) }\end{array}$ & $\begin{array}{l}3.35+0.12=3.47 \mathrm{~m}^{3} / \mathrm{s} \text {, equivalent to } \\
70 \% \text { of the pre-urbanisation discharge }\end{array}$ \\
\hline
\end{tabular}




\section{CONCLUDING REMARKS}

This paper aimed to show a discussion on possible urban drainage solutions for flood control, integrated with the urban landscape and city growth, using a case study related to a developing region in Rio de Janeiro City. Departing from a Municipality proposition for a new urban development in Guerenguê River catchment and considering the concept of compensatory techniques applied to urban drainage, a set of simulation scenarios was constructed in a mathematical model representation, ranging from the present situation to the Municipality proposal and a complementary set of storage measures distributed along the riverine areas of the main river courses. Additionally, local measures, composing multifunctional landscapes on the microdrainage scale were also introduced as complementary actions.

The obtained results show the importance of considering systemic actions, aiming to recover lost hydrological functions in the urban environment. In this context, the use of reservoirs of several types, in different scales, is very important. However, it is important to stress that real sustainable drainage solutions need to be considered together with land use control. Urban development changes the urban water cycle and this effect must be treated in an integrated way with urban drainage design in order to produce effective solutions along time.

\section{ACKNOWLEDGEMENT}

The authors acknowledge CNPq for the scholarships.

\section{REFERENCES}

[1] Batista, M., Nascimento, N. \& Barraud, S., Compensatory Techniques on Urban Drainage, ABRH: Porto Alegre, Brazil, 2005. (in Portuguese).

[2] WIT Transactions on The Built Environment, Vol 122, (C) 2012 WIT Press www.witpress.com, ISSN 1743-3509 (on-line). doi: http://dx.doi.org/10.2495/UW120201

[3] FHWA - Federal Highway Administration, Stormwater Best Management Practices in an Ultra-urban Setting: Selection and Monitoring, FHWA-EP-00-002. U.S. Department of Transportation: Washington, DC, 2000.

[4] US EPA - United States Environmental Protection Agency, The Use of Best Management Practices (BMPs) in Urban Watersheds, ed. S. Muthukrishnan, B. Madge, A. Selvakumar, R. Field \& D. Sullivan, EPA/600/R-04/184. Office of Research and Development: Washington, DC, 2004.

[5] Elliott, A.H. \& Trowsdale, S.A., A review of models for low impact urban stormwater drainage. Environmental Modelling and Software, 22(3), pp. 394-405, 2007. doi: http://dx.doi. org/10.1016/j.envsoft.2005.12.005

[6] US EPA - United States Environmental Protection Agency, Low Impact Development A Literature Review, EPA-841-B-00-005. Office of Water: Washington, DC, 2000.

[7] Coffman, L.S., Cheng, M., Weinstein, N. \& Clar, M., Low-impact development hydrologic analysis and design. In Proceedings of the 25th Annual Conference on Water Resources Planning and Management, American Society of Civil Engineering: Chicago-Illinois, New York, pp. 1-8, 1998.

[8] Woods-Ballard, B., Kellagher, R., Martin, P., Bray, R. \& Shaffer, P., The SUDS Manual. CIRIA C697, CIRIA: London, 2007.

[9] Argue, J.R. (ed.), WSUD: Basic Procedures for 'Source Control' of Stormwater - A Handbook for Australian Practice, Urban Water Resources Centre, University of South Australia: Adelaide, 2004. 
[10] Melbourne Water, WSUD Engineering Procedures: Stormwater, CSIRO Publishing: Collingwood, Australia, 2005.

[11] Coombes, P.J., Argue, J.R. \& Kuczera, G., Figtree place: a case study in Water Sensitive Urban Development (WSUD). Urban Water, 1, pp. 335-343, 1999. doi: http://dx.doi.org/10.1016/ $\underline{\mathrm{S} 1462-0758(00) 00027-3}$

[12] Hall, K.B. \& Porterfield, G.A., Community by Design, McGraw Hill: USA, 2001.

[13] Miguez, M.G., Mascarenhas, F.C.B. \& Magalhães, L.P.C., Multifunctional landscapes for urban flood control: the case of Rio de Janeiro (Chapter 2). Flood Prevention and Remediation, ed. F.C.B. Mascarenhas, WIT Press: Southampton, Boston, pp. 33-52, 2011.

[14] Miguez, M.G., Mascarenhas, F.C.B. \& Magalhães, L.P.C., Multifunctional Landscapes for Urban Flood Control in Developing Countries. The International Journal of Sustainable Development and Planning, Vol. 2, Issue 2, Southampton, UK, 2007.

[15] Google Earth, www.google.com/earth.

[16] PAC, www.brasil.gov.br/pac.

[17] Mascarenhas, F.C.B., Toda, K., Miguez, M.G. \& Inoue, K., Flood Risk Simulation, WIT PRESS: Southampton and Boston, p. 436, 2005.

[18] Mascarenhas, F.C.B. \& Miguez, M.G., Urban flood control through a mathematical cell. Water International, 27, pp. 208-218, 2002. doi: http://dx.doi.org/10.1080/02508060208686994

[19] Miguez, M.G., Flow Cell Mathematical Model to Urban Catchments. D.Sc. Thesis. Universidade Federal do Rio de Janeiro. Rio de Janeiro, RJ, Brasil, p. 301, 2001. (in Portuguese). 